Fundação Getulio Vargas

Founded 1944. Higher education establishment dedicated to social sciences research to develop the socio-economic position of Brazil. Research covers business, citizenship, education, finance, justice, health, history, law, macro and microeconomics, politics, pollution, poverty and unemployment, sustainable development and welfare.

Address: Praia de Botafogo 190, Rio de Janeiro, 22250-900

Brazil.

Website: http://www.fgv.br

President: Carlos Ivan Simonsen Leal.

\section{German Council on Foreign Relations}

Founded 1945. Independent, non-partisan and non-profit membership organization and think tank that promotes public debate on foreign policy. Research programmes focus on: China; energy policy; European integration; global economics; international security policy; Middle East; Russia/Eurasia; transatlantic relations.

Address: Rauchstrasse 17-18, 10787 Berlin, Germany.

Website: https://dgap.org

President: Dr Arend Oetker.

\section{German Development Institute (DIE)}

Founded 1964. One of the leading think tanks for global development and international co-operation worldwide. It develops policy-relevant concepts, advises ministries, governments and international organizations, and refers to current policy issues. Research areas: bi- and multilateral development co-operation; sustainable economic and social development; governance, statehood and security; environmental policy and natural resources management; world economy and development financing.

Address: Tulpenfeld 6, 53113 Bonn, Germany.

Website: http://www.die-gdi.de

Director: Dirk Messner.

\section{German Institute for International and Security Affairs (Stiftung Wissenschaft und Politik; SWP)}

Founded 1962. Independent scientific establishment that conducts practically oriented research on the basis of which it then advises the Bundestag and the German federal government on foreign and security policy issues. Research divisions: EU integration; EU external relations; international security; the Americas; Russian Federation/CIS; Middle East and Africa; Asia; global issues.

Address: Ludwigkirchplatz 3-4, 10719 Berlin, Germany.

Website: http://www.swp-berlin.org

Director: Prof. Dr Volker Perthes.

\section{Heritage Foundation}

Founded 1973. Conservative think tank aiming to formulate and promote public policies based on the principles of free enterprise, limited government, individual freedom, traditional American values and a strong national defence. Target audience includes members of Congress, key congressional staff members, policymakers in the executive branch, the news media, and the academic and public policy communities.

Address: 214 Massachusetts Ave., NE, Washington, D.C., 20002-4999, USA.

Website: http://www.heritage.org

President: Kay Coles James.

\section{Human Rights Watch}

Founded 1978. Non-profit, non-governmental organization dedicated to protecting the human rights of people around the world. Research topics include: arms; children's rights; counterterrorism; disability rights; health; international justice; migrants; press freedom; refugees; terrorism; torture; women's rights.

Address: 350 Fifth Avenue, 34th floor, New York,

NY 10118-3299, USA.

Website: http://www.hrw.org

Executive Director: Kenneth Roth.

\section{Institute for Defence Studies and Analyses (IDSA)}

Founded 1965. Non-partisan, autonomous body funded by the Indian ministry of defence that has played a key role in shaping India's foreign and security policies. It aims to promote national and international security by generating and disseminating knowledge on defence and security-related issues.

Address: 1 Development Enclave, Rao Tula Ram Marg,

New Delhi 110010, India.

Website: http://www.idsa.in

Director General: Jayant Prasad.

\section{Institute of World Economy and International Relations}

Founded 1956. Non-profit organization that carries out applied socio-economic, political and strategic research. Research areas include: current global problems; economic theory; economic, social and political problems of the transition period in Russia; forecasting and analysis of world economy dynamics and socio-political developments; international politics; military and strategic problems; theory of international relations; theory of social and political processes.

Address: 23 Profsoyuznaya St., Moscow 117997, Russia.

Website: http://www.imemo.ru

Director: Alexander A. Dynkin.

\section{International Crisis Group}

Founded 1995. Independent, non-profit organization committed to preventing and resolving deadly conflict. Combines fieldbased analysis, policy advice and high-level advocacy to highlight potential future conflicts, resolve peace negotiations and advise governments and intergovernmental bodies.

Address: 149 avenue Louise, Level 24, B-1050 Brussels, Belgium.

Website: http://www.crisisgroup.org

President: Robert Malley.

\section{International Institute for Strategic Studies (IISS)}

Founded 1958. Independent organization, considered the world's leading authority on political-military conflict. Research programme themes: conflict; defence and military analysis; economics and conflict resolution; non-proliferation and disarmament; transnational threats and international political risk; transatlantic dialogue on climate change and security.

Address: Arundel House, 13-15 Arundel St., Temple Place, London, WC2R 3DX, UK.

Website: http://www.iiss.org

Director-General: Dr John Chipman. 